\title{
Leguminosae Lectins as Biological Tools in Medical Research: a Review
}

\author{
Paula Perazzo de Souza Barbosa ${ }^{1^{*}}$ \\ http://orcid.org/0000-0001-8468-2309 \\ Francielly Negreiros de Araújo ${ }^{2}$ \\ https://orcid.org/0000-0002-7631-7077

\section{Joellington Marinho de Almeida ${ }^{1}$} \\ https://orcid.org/0000-0003-4747-1398 \\ Tatiane Santi Gadelha ${ }^{2}$ \\ https://orcid.org/0000-0001-9451-9820
}

${ }^{1}$ Federal University of Paraiba, Graduate Program in Food Science and Technology, João Pessoa, Brazil; ${ }^{2}$ Federal University of Paraiba, Department of Molecular Biology, João Pessoa, Paraiba, Brazil.

Editor-in-Chief: Paulo Vitor Farago

Associate Editor: Jane Manfron Budel

Received: 2020.03.24; Accepted: 2020.09.10.

${ }^{*}$ Correspondence: paulabio05@hotmail.com; Tel.: +55-83-996007929 (P.P.S.B.).

\section{HIGHLIGHTS}

- Leguminous lectins are proteins found in various parts of leguminous plants.

- Leguminous lectins are versatile in the carbohydrate binding specificity.

- Leguminous lectins have antimicrobial, antioxidant and antiproliferative features.

- Leguminous lectins are promising molecules for the design of new drugs.

\begin{abstract}
Lectins were discovered first in plants and later in other living things, and nowadays it is known that they are present in almost all many life forms. These proteins can bind to specific carbohydrates, which make them perform a number of biological activities and can be used as tools in the study of glycoconjugate structures present on the cell surface, being effective in medical research. Plant lectins, leguminosae lectins particularly, are among the most studied plant proteins. They are very versatile molecules, which show several interesting biological properties. Thus, the present paper reviewed the advances about the leguminosae lectins biological properties studies in the last ten years, taking into account their possible applications in the fields of Clinical Microbiology, Pharmacy and Cancerology through a search in the electronic databases, providing opportunity to exchange information about the theme. Leguminosae lectins can neutralize pathogenic organisms, be they viruses, prokaryotes and eukaryotes, in addition carcinogenic cells, besides decreasing oxidative stress, conditions which increases the possibility of alternative substances for the design of new drugs to be used in current therapeutic, expanding the possibilities of diseases cure.
\end{abstract}


Keywords: plant lectins; biological activities; applications.

\section{INTRODUCTION}

Lectins are a heterogeneous group of proteins that were first discovered in plants and subsequently in other living things such as microorganisms and humans [1]. They have non-immune origin [2] and at least one non-catalytic binding domain that interacts reversibly with carbohydrates in the form of specific monoand oligosaccharides without altering their structure [3]. These proteins have a remarkable diversity of specificity to carbohydrates, as well as specificity of recognition and binding to them [4]. The affinity to carbohydrate allows them to bind to glycoconjugates in cell surfaces, being able to promote cell agglutination, recognition or information modulation [5]. Thus, with these features, lectins can be used as tools in medical research [6].

Infectious and non-infectious diseases have always been present since the dawn of humanity, and necessitate constant research to find a cure or increase the life expectancy of patients. Considering the various diseases and the infectious agents beside its consequences, which affect the human species, the medical research is growing increasingly, paying attention to the need to search for biorecognition molecules from natural sources, for diagnosis and treatment [7]. For many years, the humanity has used plants as source of medicine [8]. Indeed, plants are endowed with chemical compounds that can have therapeutic action.

Leguminosae is a well-known plant family with cosmopolitan distribution and morphological, physiological and ecologically diverse, which represents one of the most spectacular examples of plant evolutionary diversification [9]. Leguminosae lectins form a large group of homologous proteins found in seeds and other leguminosae plants structures, and they are versatile in the carbohydrate binding specificity [10]. In leguminosae seeds, the amounts of these proteins are generally similar to those present in other tissues of the same plant [11].

Leguminosae lectins have constantly been theme in studies [12]. Thus, the present paper made a review with systematic intention about the advances in last ten years concerning studies of leguminosae lectins biological properties, taking into consideration the fields of Clinical Microbiology, Pharmacy and Cancerology, important areas of medical research, to assist the information exchange about the state of studies about lectins, and boost future clinical investigations.

\section{MATERIAL AND METHODS}

To elaborate this review paper, a search for articles was made on the electronic databases Medline (PubMed), ScienceDirect, Scopus, Google Scholar and Scielo using the key search terms: "lectins", "leguminosae lectins", "antiproliferative leguminosae lectins", "anticancer leguminosae lectins", "antifungal leguminosae lectins", "antibacterial leguminosae lectins", "antioxidant leguminosae lectins", "leguminosae lectins and oxidative stress". The inclusion criteria of articles used in construction this review were: (i) the period of publication, being selected published articles between 2010 and 2019; (ii) the studies with the leguminosae lectins, which should be directed to antibacterial, antifungal, antiviral, antioxidant and anticancer/antiproliferative properties; (iii) effectiveness of studied leguminosae lectins in relation to biological activities covered by the aims this article. The results comprised a synthesis of statistical or narrative data of the selected articles according to the mentioned criteria.

\section{RESULTS}

\section{Applications of leguminosae lectins in medical research}

\section{Antibacterial activity}

The use of antimicrobials to treat fungal and bacterial infections has greatly reduced mortality rates in humans and animals [10]. However, pathogenic microorganisms, such as bacteria, can naturally acquire resistance to these substances, and their uncontrolled use can accelerate the process [13]. Infectious diseases are the leading cause of premature deaths. In recent years, the resistance of human pathogenic bacteria to antimicrobials has been well reported, an alarming situation in both developing and developed countries due to their indiscriminate use [14]. 
Bacteria can also form biofilms, which are multicellular communities enclosed in a self-produced polymeric matrix and capable of binding to surfaces, such as artificial joints, contact lenses, catheters, teeth [15], which can cause serious health problems [16] because are involved in most bacterial infections in humans [17]. So, the search for new compounds capable of eradicating them becomes important [18]. In these cases, leguminosae lectins represent valuable instruments in the interaction study between carbohydrates present in eukaryotic cells and pathogens, being useful for discovering the development of infectious diseases and for developing of strategies for microbial control [19].

Lectin isolated from Crotalaria spectabilis Roth seeds agglutinates Leptospira interrogans and Leptospira biflexa cells, and can be used for the diagnosis and treatment of leptospirosis [6]; and Bauhinia variegata $L$. lectin seed (BVL) exhibit significant antibacterial effect on Pseudomonas aeroginosa, Staphylococcus aureus, Escherichia coli and Bacillus subtilis, whose the diameters of inhibition zones were $20 \mathrm{~mm}, 18 \mathrm{~mm}$, $20 \mathrm{~mm}$ and $18 \mathrm{~mm}$ for the four strains, respectively, by agar ditch diffusion method [14]. Acacia farnesiana L. (Willd) lectin-like protein (AFAL) showed bacterioestatic effects in Xanthomonas axonopodis pv. Passiflorae (Gram-negative) and Clavibacter michiganensis michiganensis (Gram-positive), reducing their growth rate to $50 \%$ and the cell viability to $83.4 \%$ at concentration, for each strain, of $286.5 \mu \mathrm{g} \mathrm{mL}^{-1}$ and 148.4 $\mu \mathrm{g} \mathrm{mL} \mathrm{m}^{-1}$, respectively [20]

The lectin isolated from Calliandra surinamensis Benth. leaf (CasuL) revealed bacteriostatic effect, inhibiting Staphylococcus saprophyticcus and S. aureus growth; and was also able to reduce biofilm formation by $S$. saprophyticcus $\left(72 \%\right.$ at $800 \mu \mathrm{g} \mathrm{mL}^{-1}$ ) and $S$. aureus (non-exposed data), being a dosedependent effect for the first [21]; Apuleia leiocarpa (Vogel) J.F. Macbr. seed lectin (ApulSL) demonstrated bacteriostatic effect on Bacillus subtilis, Bacillus cereus, Enterococcus faecalis, Micrococcus luteus, Streptococcus pyogenes and S. aureus cells (Gram positive), whose Minimum Inhibitory Concentration (MIC) ranged between $45.12 \mu \mathrm{g} \mathrm{mL}^{-1}$ and $180.5 \mu \mathrm{g} \mathrm{mL}-1$; and in Xanthomonas campestris pv. campestris, Xanthomonas campestris pv. viticola, Xanthomonas campestris pv. malvacearum, Klebsiella pneumoniae, Escherichia coli, Pseudomonas aeruginosa and Salmonella enteritidis (Gram-negative), whose MIC ranged between $11.12 \mu \mathrm{g} \mathrm{mL}^{-1}$ and $180.5 \mu \mathrm{g} \mathrm{mL}-1$, and it was bactericidal only against three pathovars of $X$. campestris [22].

In the work by Klafe and coauthors [23], three variants of $B$. variegata lectin I (BVL-I) - one from plant seeds and the other two, recombinants produced by Pichia pastoris and E. coli, inhibited the initial adhesion of oral bacteria in an in vitro model of biofilm formation and bacterial adhesion in a dose-dependent manner. The seed BVL-I inhibited the adhesion in $86 \%\left(200 \mu \mathrm{g} \mathrm{mL}^{-1}\right)$ of Staphylococcus mutans and Streptococcus sanguinis; BVL-I produced by P. pastoris blocked the adhesion of S. mutans in $43 \%\left(10 \mu \mathrm{g} \mathrm{mL}^{-1}\right), 65 \%(100$ $\left.\mu \mathrm{g} \mathrm{mL}^{-1}\right)$ and $74 \%\left(200 \mu \mathrm{g} \mathrm{mL}^{-1}\right)$, and of $S$. sanguinis in $47 \%\left(10 \mu \mathrm{g} \mathrm{mL}^{-1}\right), 68 \%\left(100 \mu \mathrm{g} \mathrm{mL}^{-1}\right)$, and $77 \%(200$ $\left.\mu \mathrm{g} \mathrm{mL} \mathrm{L}^{-1}\right)$. Data for E. coli weren't exposed.

The antibacterial activity of Parkia platycephala lectin (PPL) was evaluated against $S$. aureus, E. coli and $P$. aeruginosa and for all of them, the MIC was $\geq 1.024 \mu \mathrm{g} \mathrm{mL}^{-1}$, not being considered relevant clinically, because MIC values greater than $1 \mathrm{\mu g} \mathrm{mL}^{-1}$ don't have direct antibacterial activity in clinical practice. However, PPL increased the antibiotic gentamicin activity against $S$. aureus and E. coli, reducing the MIC from 64 to $25.4 \mu \mathrm{g} \mathrm{mL}^{-1}$, and from 32 to $20.2 \mu \mathrm{g} \mathrm{mL}^{-1}$, respectively. These values correspond to a reduction of $36.9 \%$ and $61.0 \%$ in the amount of gentamicin needed to have the same effect for each strain, respectively. On the other hand, PPL showed no significant effect on the modulation of gentamicin activity against $P$. aeruginosa, probably due to the bacterial extracellular polysaccharides, which form an extra barrier against the influx of drugs [24].

Lectins from seeds of Pisum sativum L. (PSA), Lens culinaris Medik. (LCA) and Canavalia ensiformis L. (DC.) (ConA) exert bacteriostatic effect against $S$. aureus, B. subtilis, E. coli and $P$. aeruginosa cells, with diameter of zone of inhibition ranged between of $7.36 \pm 0.45$ and $16.26 \pm 0.72$ and MIC of $1 \mathrm{mg} \mathrm{mL}^{-1}$ for all of them [25]. Zihua snap bean, a Phaseolus vulgaris L. variety distributed in Chinese northeast, has a lectin which exhibits antibacterial activity in a bacteriostatic way too against $S$. aureus, E. coli, and B. subtilis, and the inhibition halo diameter was concentration-dependent [26], and a lectin from Tamarindus indica seeds (EMtL6), in a preliminary study, showed more capability to agglutinate Salmonella typhimurium and S. aureus [27].

Bacterial cell surfaces are lined with diverse and abundant carbohydrates such as lipopolysaccharides and peptide glycans. The streptococcal bacteria capsule is formed by mannose and glycosidic residues, for example. From this assumption, the interaction between lectins and glycoconjugates on the bacterial surface can agglutinate cells and inhibit their growth [28], as well as adhesion to surfaces, which also influences 
biofilm formation $[18,23]$. So, leguminosae lectins have potential for the development of novel antimicrobials for the treatment of bacterial infections.

\section{Antifungal activity}

Advances in therapy have considerably increased the survival of patients who have impaired immune system function, and risk factors accumulate, favoring the progression of other diseases, such as those caused by fungi [29]. Just like bacteria, fungi that cause these infections can also acquire antimicrobial resistance when antimicrobial are misused, and lectins from leguminosae plants have shown to be effective against clinically important fungi.

Fungi are also a threat to important commercial plants, because their infections significantly reduce quality and yield, often leading to the loss of the whole plant [30], added to the fact that some of these fungi can infect humans depending on the circumstances - host jump [31], making it is also necessary to search for natural antimicrobials to combat these problems that can affect crops, and lectins with antifungal action have attracted attention due to their ability to prevent pathogenic plant fungi [32].

The lectin C-25 isolated from Cicer arietinum L. possess antifungal activiy against Candida krusei, Candida tropicalis and Candida parapsilosis, with values of MIC between 1.56 and $12.5 \mu \mathrm{g} \mathrm{L}^{-1}$. It also inhibits the growth of fungal strains which are resistant and susceptible-dose dependent to fluconazole [33] and reduces growth by $85 \%$ of $C$. krusei, and by $81 \%$ of Fusarium oxysporum [34]. Archidendron jiringa (Jack) I.C. Nielsen seeds lectin (AJL) was also tested for its antimicrobial activity against Candida albicans, Exserohilum turcicum, F. oxysporum and Colletotrichum cassiicola [35]. The latter causes phaeohyphomycosis, an opportunistic ill which infects humans including superficial, cutaneous and subcutaneous infection [36].

Bauhinia ungulata $\mathrm{L}$. seeds lectin (BUL) was able to reduce the radial growth of Fusarium solani and Fusarium moniliform by 40 and 30\%, respectively [37]. Fungi of Aspergillus genus are the most common associated to fruit rot during storage, but can also cause aspergillosis in humans [38]. In a study with protein from seeds native Amazonian plants, Ramos and coauthors [39] identified lectin in Dimorphandra parviflora Benth., whose extract showed action against the fungi Aspergillus favus and Aspergillus niger. Candida fungi are among the most isolated in clinical mycology laboratories [40]. Although they are part of the human microbiota, they can cause opportunistic infections [41], being a health problem, especially for immunocompromised patients. The CasuL, lectin isolated from $C$. surinamensis leaf was tested against $C$. krusei showed sensitivity to it, with drastic morphological changes, retraction of cytoplasmic content and cell disruption [21]

Fusarium fungi affect plants, but can cause opportunistic infections in humans. Swartzia longistipitata Ducke lectin showed antimicrobial activity against $F$. oxysporum [39]. The lectins of $P$. vulgaries (named PL by authors) and Glycine max (L.) Merr. (named LG by authors) were tested against this same fungus and LP was the most potent among the tested compounds, with $\mathrm{EC}_{50}$ of $5058 \mathrm{mg} \mathrm{L}^{-1}, 4872 \mathrm{mg} \mathrm{L}^{-1}$ and $3617 \mathrm{mg} \mathrm{L}^{-1}$, after $48 \mathrm{~h}, 72 \mathrm{~h}$ and $120 \mathrm{~h}$, respectively. In contrast, the LG was the lowest active, with $\mathrm{EC}_{50}$ of $13982 \mathrm{mg} \mathrm{L}^{-}$ ${ }^{1}, 9449 \mathrm{mg} \mathrm{L}^{-1}$ and $5635 \mathrm{mg} \mathrm{L}^{-1}$ after $48 \mathrm{~h}, 72 \mathrm{~h}$ and $120 \mathrm{~h}$ against the same fungus [42].

Lunatin, a Phaseolus lunatus Billb. ex Beurl. lectin inhibited the growth of fungi Pythium aphanidermatum, F. solani, F. oxysporum, and Botrytis cinereal, and this inhibition was concentration-depending (not-shown data) [30]. Phaseolus vulgaris 'Chinese Pinto Beans' lectin (CPBL) inhibited the mycelium growth of Valsa mali by $30.6 \%$ at $30 \mu \mathrm{M}$ [43]. Gomes and coauthors [44] verified the Dioclea rostrata (DRL), Canavalia brasiliensis (ConBr) and Dioclea violacea (DvioL) lectins antifungal activity against isolated fungi from vaginal secretions. Four of the isolates, Candida guilliermondii (URM4975), Candida shehatae (URM4978), Candida membranaefaciens (URM4983) and Kloeckera apiculata (URsilvM5002) were sensitive to the three lectins, with average geometric concentrations ranging from 2 a $256 \mu \mathrm{g} \mathrm{mL}^{-1}$.

A likely way which the lectins can act against fungi is by pelleting their cells when dealing with yeast forms [45] or by promoting membrane permeability of their spores [41]. Another approach is based on the fact that many plant lectins can be chitinase-like proteins that act by breaking chitin glycosidic bonds and breaking down the fungal cell wall [46], which is mainly composed by the chitin polysaccharide [47]. Thus, spore germination is compromised and the microorganism cannot develop [34]. Therefore, from the exposed results, we can reaffirm that leguminosae lectins have potential for the development of novel antimicrobials for the treatment of fungal infections. 


\section{Antiviral activity}

Compounds with antiviral activity are of great medical interest [48] because many life-threatening human diseases are caused by viruses and, although taxonomic and genetically distinct, they have the same basic molecular structure [49]. There are still few studies that address the use of legume lectins in the antiviral approach, when compared to studies that relate bacteria or fungi, and these proteins can be also used in the development of biosensors.

A study evaluated ConA, LCA and peanut agglutinin (PNA) antiviral activity and they showed action against human parainfluenza virus type 2 (hPIV-2). The three lectins inhibited partly hPIV-2 RNA, and largely its protein syntheses, as well as prevented viral entry into cells by binding to the cell surface lectin receptors [50]. The affinity of proteins in the envelope or viral capsid for receptors on the cell surface is a common mechanism for the recognition and viruses entry into host cells [51], and a way to prevent the establishment of infection can be done through molecules that bind to the virus and prevent the carbohydrate-mediated viral adsorption with the host cell until the immune response develops [52]. Lectins can bind to virus envelope glycoprotein glycans [53] playing an important role in preventing viral transmission and penetration into host cells. Sugar-binding proteins can crosslink sugars on the viral surface and prevent further interactions with co-receptors [48]. Lectins may also inhibit reverse transcriptase from HIV-1, such as Pisum sativum Green Split Peas lectin, with $\mathrm{IC}_{50}$ of $2 \mu \mathrm{M}$ [54]; $P$. vulgaris of the Extralong Autumn Purple Bean lectin (EAPL), with $\mathrm{IC}_{50}$ of $1.8 \mu \mathrm{M}$ [55]; and French bean lectin, with $\mathrm{IC}_{50}$ of $2 \mu \mathrm{M}$ [56]. The mechanism of action through which lectins are able to inhibit reverse transcriptase is not well known or is inconclusive, since no reports have been found in the literature.

Gondim and coauthors [57] verified the lectins of Canavalia brasiliensis (ConBr), Canavalia maritima (ConM), Dioclea lasiocarpa (DLasiL) and Dioclea sclerocarpa (DSclerL) were promising in their antiviral activity, having been tested against Influenza A (H1N1 and H3N2), Influenza B virus, HIV-1, HIV-2 and Respiratory Syncytial Virus (RSV), that cause infections in humans. The lectins exhibited $\mathrm{EC}_{50}$ values in the nanomolar range, being DSclerL and DLasiL of $9 \mathrm{nM}$ to $46 \mathrm{nM}$ for HIV-1 and RSV, respectively, and DSclerL, ConBr and ConM showed $E_{50}$ values that varied from 0.4 to $6 \mathrm{nM}$ against $\mathrm{H} 1 \mathrm{~N} 1$, H3N2 and Influenza $B$ Virus. For HIV, the evidence pointed to blocking its entry into target cells as a mechanism of these lectins with antiviral action.

The use of lectins in the development of biosensors for infectious diseases clinical diagnosis such as viruses has also been described, as is the case of lectin isolated from Cratylia mollis Mart. ex. Benth. Seeds (CramoLL), used in the development of an electrochemical biosensor for detection of abnormal glycoproteins and thus of dengue virus (DENV) serotypes in the serum of possibly contaminated patients. [58]. Another study provided experimental evidence to maintain that at $\mathrm{pH} 7.2$, DENV particles are immobilized by ConA as a result of specific recognition of glycosylated residues of viral protein $E$ and the ConA mannose binding site, with this adhesion being more selective when protein is part of the viral structure than it is free in solution [59]. The use of lectins in the diagnosis of viruses is interesting and it can eliminate the need for antibodies, reducing financial costs [60]. A gold nanoparticles-polyaniline hybrid composite (AuNpPANI) for the immobilization of Bauhinia monandra lectin (BmoLL) was more one sensitive and selective biosensor which has also been successfully developed for dengue serotyping. The AuNpPANI-BmoLL was able to detect glycoproteins from three DENV serotypes with a high specificity degree [61].

Biosensors are analytical devices that incorporate a biological sensor element and convert a response into an electrical signal [62]. Thus, the integration of biology with electronic vision and computer technology broadened the horizons of research for greater sensitivity and precision [63], since biosensors have potential uses cover from medical diagnostics to drug discovery, besides food safety, process control and environmental monitoring, for defense and security applications [64]

\section{Antioxidant activity}

Eukaryotic cells produce energy in the form of adenosine triphosphate (ATP) mainly, through metabolic pathways, such as the Krebs cycle and the electron transport chain, which lead to the ultimate reduction of molecular oxygen $\left(\mathrm{O}_{2}\right)$. The operation of metabolic pathways generates reactive oxygen species (ROS), leading to free radical synthesis [65]. However, excessive synthesis of ROS promotes oxidative stress, which can damage cellular components and cause dysfunctions [66], a factor already confirmed as contributing to the pathogenesis and pathophysiology of many chronic health problems [67].

Thus, inhibition of free radical formation provides a therapeutic strategy to prevent oxidative stress. Antioxidants may act in different ways, inhibiting the formation of reactive oxygen species, sequestering free 
radicals, or increasing enzyme defense capacity [68]. The body has natural defenses against oxidative stress, but exogenous antioxidants present in foods, such as protein amino acids, can help in the process [66]. Studies addressing the antioxidant activity of leguminosae lectins are scarce, but in the literature some of them have been described with potential property.

Some methods that evaluate antioxidant activity of compound are available, such as 2,2-diphenyl-1picrylhydraz (DPPH) and 2,2'-azinobis (3-ethylbenzothiazoline-6-sulfonic acid)33 (ABTS) Radical Scavenging Methods, which are most commonly used. The in vitro antioxidant activity of lectin from $C$. arietinum seeds was evaluated by the DPPH radical capture method and presented $\mathrm{IC}_{50}$ of $0.88 \mu \mathrm{g} \mathrm{mL} \mathrm{m}^{-1}$, higher than when ascorbic acid, antioxidant used as standard, whose value of $\mathrm{IC}_{50}$ was $0.52 \mu \mathrm{g} \mathrm{mL}^{-1}$ [34].

Lima bean (Phaseolus lunatus L. var. Cascavel) lectin exhibited relevant antioxidant action because it showed IC $\mathrm{I}_{50}$ of $4.38 \mathrm{mg} \mathrm{mL}^{-1}$ and $0.21 \mathrm{mg} \mathrm{mL}^{-1}$ for the DPPH and ABTS radical capture methods, respectively, when compared to the antioxidant activity of ascorbic acid, which was used as standard [69]. The lectin isolated from Lablab purpureus (L.) Sweet seed was submitted to the antioxidant activity test by the DPPH radical method with $\mathrm{IC}_{50}$ value of $11.43 \mathrm{mg} \mathrm{mL}^{-1}[70]$.

Two mechanisms generally stabilize free radicals: transfer of a hydrogen atom or an electron to the radical [71]. Amino acids, protein-forming units, such as tyrosine and cysteine may explain the antioxidant action of lectins for the sequestration of ABTS and DPPH radicals. Tyrosine has a hydroxyl in its side chain, and cysteine a thiol group, which can donate hydrogen to radicals.

Pinto and coauthors [72] showed that Mucuna pruriens lectin (MpLec) demonstrated gastroprotective effects on ethanol-induced lesions in mice and prevented gastric oxidative damage, improving total antioxidant capacity and the integrity of cell membranes, as well as reducing lipid peroxidation. Levels of reduced glutathione peroxidase $(\mathrm{GSH})$ and superoxide dismutase (SOD) increased in the gastric tissues of mice treated with MpLec $\left(0,1 \mathrm{mg} \mathrm{kg}^{-1}\right)$ compared to untreated animals (control). Levels of malondialdehyde (MDA) decreased after treatment with $\operatorname{MpLec}\left(0,1 \mathrm{mg} \mathrm{kg}^{-1}\right)$. MDA is an indicator of lipid peroxidation [73]. GSH has a cytoprotective function as a reducer and cofactor of certain antioxidant enzymes, a role of particular importance against oxidative stress [74], and SOD quickly converts the superoxide anion $\left(\mathrm{O}^{2}\right)$ to hydrogen peroxide $\left(\mathrm{H}_{2} \mathrm{O}_{2}\right)$ [75].

The generation of ROS in rats with Acute Kidney Injury (AKI) induced by Renal Ischemia/Reperfusion (IR) has been reduced by the administration of DVL, indicating that the administration of DVL can have a powerful effect in improving IR renal dysfunction [76]. Renal cells rich in mitochondria, which makes the kidneys highly vulnerable to damage caused by oxidative stress [77].

A lectin from Pterocarpus soyauxii Taub Seeds (PSSL) had his antioxidant potential tested using the methods: ability to scavenge DPPH radicals; to chelate metals and to inhibit lipid peroxidation. The tests showed that the PSSL has antioxidant activity in a dose-dependent manner, with $I_{50}$ of $0,14 \pm 1,33 \mathrm{mg} \mathrm{ml}^{-}$ $1,3,40 \pm 0,37 \mathrm{mg} \mathrm{ml}^{-1}$ e $0,50 \pm 0,08 \mathrm{mg} \mathrm{ml}^{-1}$ for each of the methods, respectively [78]. Pterocarpus osus Craib. lectin (POSL) also demonstrated antioxidant activity with $\mathrm{IC}_{50}$ of $1.17 \pm 0.08,0.58 \pm 0.03$, and $2.51 \pm$ $0.03 \mathrm{mg} / \mathrm{ml}$ for, respectively, for DPPH radical scavenging, lipid peroxidation inhibition and ferric reducing antioxidant potential assay [79].

Checking the chelating ability of protein is also a way of assessing its antioxidant potential, because transition metals can promote oxidative damage to biological systems. Ferrous ions, for example, are soluble in biological fluids and in the presence of oxygen or hydrogen peroxide, they generate harmful and deleterious ROS [80]. The antioxidant activity of proteins can also be assessed using the lipid peroxidation inhibition test. Lipids are responsible for maintaining the integrity of cell membranes, and an extensive peroxidation of them can alter the membrane assembly, composition, structure and dynamics, in addition, it can promote the formation of highly reactive lipid peroxides, which can also propagate the additional generation of ROS or degrade into reactive compounds capable of cross-linking DNA and proteins [81]. Thus, drug design and development of alternative compounds to classical drugs could identify novel therapeutics [72] and so, lectins with antioxidant properties are potential pharmaceutical value tools.

\section{Effect against cancerygen cells}

Cancer develops when cell growth exceeds cell death following a loss in control of the fundamental cellular checkpoints needed to maintain healthy tissue renewal. This uninhibited proliferative capacity follows a deregulation in oncogenic expression that results in tumor formation [82]. This disease is a problem responsible for high mortality worldwide, and this fact leads to the need to search for new drugs, especially those that use new mechanisms of action, so that it is also possible to fight resistance [83]. In this case, cancer research, is another possible use of leguminosae lectins, being this family a representing well-defined 
and non-traditional source of anticancer compounds, becoming in recent years important tools for understanding various aspects related to the disease [84]. Since the first discovery about SBA, from soybean, which it can have a therapeutic action regarding the Walker tumor, knowledge has accumulated about plant lectins with anticarcinogenic activity; and the use of lectins in cancer research is gaining place [85].

Plant lectins may have anticancer properties and act as tools for early diagnosis and even as nanostructures recognition agents that carry antitumor compounds in cancer cells [86]. Lectins may be harmful to cancer cells, and this property may manifest through different mechanisms, usually initiated by interaction with specific receptors, glycosylated or not, on the membrane of these cells [87]. In addition, lectins also have potential as biomarkers, which can early detect malignant growth [88]. Through a study with Bauhinia forficata lectin against human breast cancer MCF7 cells, it was found that the protein induces cell death by inhibiting caspase-9, DNA fragmentation, resulting in cycle arrest in the G2/M phase, and reduced expression of $\alpha 1, \alpha 6$ and $\beta 1$ integrin subunits, preventing their adhesion to extracellular matrix components such as laminin, fibronectin and type 1 collagen [89]. The CasuL was able to reduce the viability of $\mathrm{K}_{562}\left(\mathrm{IC}_{50}\right.$ of $\left.67.04 \pm 5.78 \mu \mathrm{g} \mathrm{mL}^{-1}\right)$ and T47D $\left(\mathrm{IC}_{50}\right.$ of $\left.58.75 \pm 2.5 \mu \mathrm{g} \mathrm{mL}^{-1}\right)$ cells, chronic myeloid leukemia and human mammary carcinoma, respectively [21], and BUL has shown activity against human colon adenocarcinoma (HT-29) cells and inhibits $80 \%$ of cell growth viability at a concentration of $160 \mu \mathrm{g} \mathrm{mL}^{-1}$ [37].

Shi and coauthors [2] studied the ConA lectin anticancer effect, which induce apoptotic cell death in MCF-7 human breast carcinoma cells via induction of nuclear apoptosis Factor kappa-light-chain-enhancer of activated B cells (Nuclear Factor Kapa B, NF-K B), Signal-regulated Extracellular Kinases (ERK) and cJun $\mathrm{N}$ down-regulation kinases (c-Jun $\mathrm{n}$-Terminal kinase, JNK), cell division regulatory protein complexes; and via p53 and p21, proteins involved with apoptosis process and cell cycle regulation, respectively. The same researchers tested Sophora flavescens Ailton lectin (SFL), in MCF-7 human breast carcinoma cells and it reduced the expression of NF-KB and ERK, and increases p53 protein expression. It also triggers cell cycle arrest in the G2/M phase, increasing p21 protein expression and reducing regulation. These lectins also have an in vivo effect because they decreased the volume and weight of subcutaneous tumor in rats.

Gondim and coauthors [90] demonstrated that ConBr, ConM, DSclerL and DLasiL exhibit potential activity on a variety of breast, lung, ovarian and prostate cancer cell lines. A lectin from Phaseolus vulgaris L. 'French bean number 35' induce apoptosis in MCF-7 cells [91]; and a polygalacturonic acid-specific lectin, named BTKL, isolated from seeds of Phaseolus vulgaris L. "Blue tiger king", exerted a potent antiproliferative action on Hep G2 cells [92]; and Phaseolus vulgaris L. 'Green Dragon number 8' beans contain a glucosamine-binding lectin that could inhibit nasopharyngeal carcinoma HONE1 cells after treatment for 24 $\mathrm{h}\left(\mathrm{IC}_{50}=62.3 \mu \mathrm{M}\right), 48 \mathrm{~h}\left(\mathrm{IC}_{50}=31.6 \mu \mathrm{M}\right)$, and $72 \mathrm{~h}\left(\mathrm{IC}_{50}=28.7 \mu \mathrm{M}\right)$, preventing the cells from dividing and kept them at the G2/M phase. It also had an effect on nasopharyngeal carcinoma CNE2 cells, after 24 and $48 \mathrm{~h}$ treatment [93]. The EAPL showed antitumor activity against nasopharyngeal carcinoma (CNE-1, CNE2, HNE-2) cell lines, breast cancer cells (MCF-7) e hepatocellular carcinoma (HepG2), inhibiting their proliferation in a dose dependent manner. The test done on HepG2 showed the EAPL induced apoptosis in this strain, which was shown to be the most sensitive to the action of lectin [55]; French bean lectin also reduced the viability of MCF-7 (IC50 of $2 \mu \mathrm{M})$ and HepG2 $(100 \mu \mathrm{M})$ cells.

Lotus corniculatus lectin (LCL), from pods, showed strong antiproliferative activity against human leukemic (THP-1) cancer cells, lung cancer (HOP62) cells and colon cancer cell (HCT116), with IC I0 $_{50} 39$ $\mu \mathrm{g} \mathrm{mL}^{-1}$ and $50 \mu \mathrm{g} \mathrm{mL}^{-1}$ e $60 \mu \mathrm{g} \mathrm{mL}^{-1}$, respectively. Besides that, LCL inhibited, in a dose-dependent manner, the migration of THP-1 cells, which is a stage in metastases [94]. ConA $\left(\mathrm{IC}_{50}\right.$ of $\left.3 \mu \mathrm{g} \mathrm{mL}^{-1}\right)$ and ConBr lectins $\left(\mathrm{IC}_{50}\right.$ of $\left.20 \mu \mathrm{g} \mathrm{mL}^{-1}\right)$ induce cell death in human leukemia MOLT-4 and HL-60 cell lines and promote apoptosis with DNA fragmentation, mitochondrial depolarization and increased ROS production, in addition to a DNA damage rate greater than $80 \%$ in cells [95].

Another lectin with significant activity on cancer cells is Erophaca baetica (L.) Boiss. seed isolate, which had an inhibitory effect of $50 \%$ on the proliferation of human leukemic THP-1 cells at a concentration of 12 $\mu \mathrm{g} \mathrm{mL} \mathrm{L}^{-1}$ [12]. A lectin from the seeds of the medicinal plant Pisum fulvum Sibth. \& Sm. was examined for activity anticancer against colorectal adenocarcinoma (Caco-2), HepG2, MCF7 and laryngeal carcinoma (Hep-2 cells) and the lectin was more potent against HepG2 cells with inhibition percentages ranged from $68.45 \%$ to $90.98 \%$. Treated HepG2 cells with lectin showed obvious nuclear condensation after $48 \mathrm{~h}$ of treatment with ability to down-regulate the expression of BCL2 and BAX genes and to up-regulate the expression of Ikab gene, that promote the inhibition of NF-kB inflammatory pathway [96].

Lunatin exerted antiproliferative activity on K562 leukemia cells, inhibiting their proliferation $\left(\mathrm{IC}_{50}=15\right.$ $\mathrm{mM}$ ) and inducing morphological abnormalities [32]. CPBL exhibited moderate antiproliferative activity 
against nasopharyngeal carcinoma cells (HONE-1) in a dose and time dependent manner, with after incubation for $24 \mathrm{~h}\left(\mathrm{IC}_{50}\right.$ of $\left.30.8 \mu \mathrm{M}\right)$ and $48 \mathrm{~h}\left(\mathrm{IC}_{50}\right.$ of $\left.17.3 \mu \mathrm{M}\right)$ [43].

Panda and coauthors [3] showed that lectin of soybean (SBL) have cytotoxic effect on cervical cancer (HeLa), oral cancer (Hep2), HepG2, breast cancer (MDA MB 231) and glioblastoma (U373) MG cell lines, with $\mathrm{IC}_{50}$ of $60.13 \pm 3.5,20.8 \pm 1.2,40.6 \pm 6.1,40.1 \pm 7.7,51.0 \pm 7.8 \mu \mathrm{g} / \mathrm{ml}$, respectively, in a dose and time dependent manner too. In the same work, the authors verified the therapeutic efficacy in mice with Dalton's lymphoma (DL) and saw a significant reduction in the volume of abdominal fluid and in the number of DL cells in the animals treated with SBL in comparison with the control mice, with a reduction in the survival of cancer cells of $74,51 \pm 3,5 \%$ and $82,95 \pm 5,8 \%$ on the 10 th day for doses of 1 and $2 \mathrm{mg} \mathrm{kg}^{-1}$ respectively. Dalton's lymphoma is widely used as a model for cancer research, in the preclinical system in the evaluation of new or known drugs in the treatment of various types of cancer, because it is already well characterized, reproducible and established, and has been the basis drug development. [97]

ConBr had its effect tested on B16F10 murine melanoma cells and inhibited cell growth in a dosedependent manner. After incubated at a concentration of $10 \mu \mathrm{g} \mathrm{mL}^{-1}$ with the cells, for $24 \mathrm{~h}$, it inhibited about $76 \%$ of cell growth. ConBr also induced NO and IL-12 synthesis [98]. Murine is the most used preclinical model for the study of melanoma, due to its ubiquity in addition to its facility of manipulation and availability, as well as the existing knowledge about its genetics [99].

Lectins of seeds from Canavalia virosa (ConV) [100], Dioclea lasiophylla (DlyL) [101] and Dioclea violacea (DLV) [102] induced toxicity in rats C6 glioma cells, promoting morphological cell changes, from adherent to spherical, as well as alteration in the mitochondrial membrane potential. In the DVL assay, debris characteristic of extracellular matrix degradation was also observed. The cellular response was dependent on its concentration and the incubation period. The induction of cell death was mainly in the highest concentrations and in the longest incubation periods $-100 \mu \mathrm{g} \mathrm{mL} \mathrm{L}^{-1}$ after $48 \mathrm{~h}$ for the three lectins. The C6 mouse glioma model is one of the most used experimental models in neuro-oncology to study the growth and invasion of high-grade gliomas, as it resembles human GBM better than another model of rodent glioma, including genetics [103]

The level of cytotoxicity of lectins is variable, and their potential for effective use as antitumor agents is depending of their specificity to cancer cells [21], since glycosylation pattern changes between different cells [104]. An extrinsic pathway is activated on the cell surface when a specific ligand binds to its receptor [105], leading to apoptosis of malignant cells $[2,55,91,95]$. Apoptosis is a programmed cell death with different biochemical and genetic pathways that plays a critical role in the development and balance of healthy tissues, contributing to the elimination of unnecessary and unwanted body problems [106].

\section{CONCLUSIONS}

Since its discovery, plant lectins have been used as tools in medical research, and its study is growing. The principle of their biological activities is based on the properties of recognition and interaction with specific carbohydrates, which differentiate them from other proteins. Leguminosae lectins are versatile molecules that can neutralize viruses, prokaryotic and eukaryotic cells, and decrease oxidative stress, which increases the possibility of alternative substances for the design of new antimicrobial, antineoplastic and antioxidant drugs, which could be used in current therapeutic, expanding the diseases cure possibilities. Leguminosae lectins can also be used as biomarkers and instruments for the development of biosensors, useful in the illness diagnosis such as cancer and viruses. Although in the current scenario of research with plant lectins is stimulating, with promising results in relation to biological properties that have potential for application in the field of human health, these molecules need further investigation, and additional tests are essential to verify its mechanisms of action, toxicity in living systems, and establish efficacy, optimize dosage, administration and bioavailability

Conflicts of Interest: The authors declare no conflict of interest. 


\section{REFERENCES}

1 Gong T, Wang X, Yang Y, Yan Y, Yu C, Zhou R, et al. Plant Lectins Activate The NLRP3 Inflammasome To Promote Inflammatory Disorders. J Immunol. 2017;198(5):2082-92.

2 Shi Z, Chen J, Li CY, An N, Wang ZJ, Yang SL, et al. Antitumor effects of concanavalin A and Sophora flavescens lectin in vitro and in vivo. Acta Pharmacolog. 2014;35(2):248-56.

3 Panda PK, Mukhopadhysay S, Behera B, Bhol CS, Dey S, Das DN, et al. Antitumor effect of soybean lectin mediated through reactive oxygen species-dependent pathway. Life Sci. 2014;111(1-2):27-35.

4 Abhinav KV, Samuel E, Vijayan M. Archeal lectins: An identification through a genomic search. Proteins. 2016;84(1):21-30.

5 Bun $\mathrm{Ng} \mathrm{T}$, Chi Fai Cheung R, Cheuk Wing Ng C, Fei Fang E, Ho Wong J. A review of fish lectins. Curr Protein Pept Sci. 2015;16(4):337-51.

6 de Oliveira WR, Rego EJL, Ristow PCLVB, da Silva Velozo E, de Carvalho Carneiro D, Bastos BL, et al. Isolation, characterization and analysis of the agglutinative activity of a lectin from Crotalaria spectabilis. J Plant Biochem and Biotechnol. 2018;27(4):373-81.

7 Coelho LCBB, Silva PMS, Lima VLM, Pontual EV, Paiva PMG, Napoleão TH, Correia MTS. Lectins, Interconnecting Proteins with Biotechnological/Pharmacological and Therapeutic Applications. Evid-based Compl Alt. 2017;2017:1-23.

8 Chatterjee S, Biswas G, Basu SK, Acharya K. Antineoplastic effect of mushrooms: a review. Aust J of Crop Sci. 2011;5(7):904-11.

9 Azani N, Babineau M, Bailey CD, Banks H, Barbosa AR, Pinto RB, et al. A new subfamily classification of the Leguminosae based on a taxonomically comprehensive phylogeny. Taxon. 2017;66(1):44-77.

10 Lagarda-Diaz I, Guzman-Partida AM, Vazquez-Moreno L. Legume Lectins: Proteins with Diverse Applications. Int J Mol Sci. 2017;18(6):1-18.

11 Gulzar H, Gul J, Hassan G. Protein profiles of phytoagglutinins from indigenous species of euphorbiaceae, leguminosae and moraceae from Pakistan. Pak J Bot. 2015;47:119-26.

12 Megías C, Cortés-Giraldo I, Girón-Calle J, Alaiz M, Vioque J. Purification of an Antiproliferative Lectin from Erophaca Baetica (Leguminosae) Seeds. J Food Nutr Res. 2013;1(5):87-91.

13 Silva PM, Napoleão TH, Silva LC, Fortes DT, Lima TA, Zingali RB. The juicy sarcotesta of Punica granatum contains a lectin that affects growth, survival as well as adherence and invasive capacities of human pathogenic bacteria. 2016; J Funct Foods;27:695-702.

14 Mishra RP, Ganaie AA, Allaie AH. Isolation and purification of a Galactose specific lectin from seeds of Bauhinia variegata and evaluation of its antimicrobial potential. Int J Pharm Sci Res. 2016;7(2):804-15.

15 Buommino E, Scognamiglio M, Donnarumma G, Fiorentino A, D'Abrosca B. Recent Advances In Natural ProductBased Anti-Biofilm Approaches To Control Infections. Mini Rev Med Chem. 2014;14(14):1169-82.

16 Ren Y, Jongsma MA, Mei L, van der Mei HC, Busscher HJ. Orthodontic treatment with fixed appliances and biofilm formation - a potential public health threat? Clin Oral Investig. 2014;18(7):1711-8.

17 Wu H, Moser C Wang HZ, Høiby N, Song ZJ. Strategies for combating bacterial biofilm infections. Int J Oral Sci. 2015;7(1):1.

18 Vasconcelos MA, Arruda FVS, Carneiro VA, Silva HC, Nascimento KS, Sampaio AH et al. Effect of Algae and Plant Lectins on Planktonic Growth and Biofilm Formation in Clinically Relevant Bacteria and Yeasts. BioMed Res Int. 2014;2014:1-9.

19 lordache F, Ionita M, Mitrea LI, Fafaneata C, Pop A. Antimicrobial and Antiparasitic Activity of Lectins. Curr Pharm Biotechnol. 2015;16(2):152-61.

20 Santi-Gadelha T, Rocha BAM, Gadelha CAA, Silva HC, Castellon RER, Gonçalves FJT. Effects of a lectin-like protein isolated from Acacia farnesiana seeds on phytopathogenic bacterial strains and root-knot nematode. Pestic Biochem Physiol. 2012;103(1):15-22.

21 Procópio TF, de Siqueira Patriota LL, de Moura MC, da Silva PM, de Oliveira APS, do Nascimento Carvalho L, et al. CasuL: A new lectin isolated from Calliandra surinamensis leaf pinnulae with cytotoxicity to cancer cells, antimicrobial activity and antibiofilm effect. Int J Biol Macromol. 2017;98:419-29.

22 de Souza Carvalho, da Silva MV, Gomes FS, Paiva PMG, Malafaia CB, da Silva TD, et al. Purification, characterization and antibacterial potential of a lectin isolated from Apuleia leiocarpa seeds. Int J Biol. Macromol. 2015;75:402-8.

23 Klafke GB, Moreira GMSG, Pereira JL, Oliveira PD, Conceição FR, Lund RG. Lectin I from Bauhinia variegata (BVL-I) expressed by Pichia pastoris inhibits initial adhesion of oral bacteria in vitro. Int $\mathrm{J}$ Biol Macromol. 2016;93:913-8. 
24 Silva RR, Silva CR, Santos VF. Barbosa CR, Muniz DF, Santos AL, et al. Parkia platycephala lectin enhances the antibiotic activity against multi-resistant bacterial strains and inhibits the development of Haemonchus contortus. Micro Pathog. 2019;135:1-6.

25 Nair SS, Madembil NC, Nair P, Raman S, Veerabadrappa SB. Comparative analysis of the antibacterial activity of some phytolectins. Int Curr Pharm J. 2013;2(2):18-22.

26 Jiang B, Wang X, Wang L, Lv X, Li D, Liu C, Feng Z. Two-Step Isolation, Purification, and Characterization of Lectin from Zihua Snap Bean (Phaseolus vulgaris) Seeds. Polymers. 2019;11(5):1-20.

27 Osman ME, Awadallah AK, Konozy EH. Isolation Purification and Partial Characterization of Three Lectins from Tamarindus indica Seeds with a Novel Sugar Specificity. Int J Plant Res. 2016;6(1):13-9.

28 Kabir SR, Nabi MM, Nurujjaman M, Reza MA, Alam AK, Zaman RU, et al. Momordica charantia Seed Lectin: Toxicity, Bacterial Agglutination and Antitumor Properties. Appl Biochem Biotechnol. 2015;175(5):2616-28.

29 Sanglard D. Emerging Threats in Antifungal-Resistant Fungal Pathogens. Front Med. 2016;3:1-10.

30 Ray M, Ray A, Dash S, Mishra A, Achary KG, Nayak S. Fungal disease detection in plants: Traditional assays, novel diagnostic techniques and biosensors. Biosens Bioelectron. 2017;87:708-23.

31 Sharma K, Goss EM, Dickstein ER, Smith ME, Johnson JA, Southwick FS, van Bruggen AH. Exserohilum rostratum: Characterization of a Cross-Kingdom Pathogen of Plants and Humans. PloS one. 2014;9(10):1-10.

32 Wu J, Wang J, Wang S, Rao P. Lunatin, a Novel Lectin with Antifungal and Antiproliferative Bioactivities from Phaseolus lunatus Billb. Int J Biol Macromol. 2016;89:717-24.

33 Kumar S, Kapoor V, Gill K, Singh K, Xess I, Das SN, Dey S. Antifungal and Antiproliferative Protein from Cicer arietinum: a Bioactive Compound Against Emerging Pathogens. Biomed Res Int. 2014;2014:1-10.

34 Gautam AK, Gupta N, Narvekar DT, Bhadkariya R, Bhagyawant SS. Characterization of chickpea (Cicer arietinum L.) lectin for biological activity. Physiol Mol Bio Plant. 2018;24(3):389-97.

35 Charungchitrak S, Petsom A, Sangvanich P, Karnchanatat A. Antifungal and antibacterial activities of lectin from the seeds of Archidendron jiringa Nielsen. Food Chem. 2011, 126:1025-32

36 Xie Z, Wu W, Meng D, Zhang Q, Ma Y, Liu W, Chen J, et al. A case of Phaeohyphomycosis caused by Corynespora cassiicola infection. BMC Infect Dis. 2018;18(1):1-4.

37 Silva HC, Pinto LDS, Teixeira EH, Nascimento KS, Cavada BS, Silva ALC. BUL: a novel lectin from Bauhinia ungulata L. seeds with fungistatic and antiproliferative activities. Process Bioch. 2014;49(2):203-9.

38 Solanki DS, Kumar S, Parihar K, Tak A, Gehlot P, Pathak R, Singh SK. Characterization of a novel seed protein of Prosopis cineraria showing antifungal activity. Int J Biol Macromol. 2018;116:16-22.

39 Ramos MV, Brito D, Freitas CD, Gonçalves JFC, Porfirio CT, Lobo MD, et al. Proteomic identification and purification of seed proteins from native Amazonian species displaying antifungal activity. Planta. 2018;248(1):197209.

40 Lima LA, Faria MAS, de Paula Menezes R, Penatti MPA, dos Santos Pedroso R. Phenotypic Characteristics of Yeasts of the Genus Candida and Cryptococcus in Differential Culture Media. Int J Curr Microbiol App Sci. 2018;7(8):1912-21.

41 Cameron SJ, Bolt F, Perdones-Montero A, Rickards T, Hardiman K, Abdolrasouli A. Rapid Evaporative lonisation Mass Spectrometry (REIMS) Provides Accurate Direct from Culture Species Identification within the genus Candida. Sci Rep. 2016;14(6):1-10.

42 Mohsen SF, Abbassy MA, Rabea El, Abou-Taleb HK. Isolation and Antifungal Activity of Plant Lectins Against Some Plant Pathogenic Fungi. ASEJ. 2018;39:161-7.

43 Ang ASW, Cheung RCF, Dan X, Chan YS, Pan W, Ng TB. Purification and Characterization of a GlucosamineBinding Antifungal Lectin from Phaseolus vulgaris cv. Chinese pinto Beans with Antiproliferative Activity Towards Nasopharyngeal Carcinoma Cells. Appl Biochem. 2014;172(2):672-86.

44 Gomes BS, Siqueira ABS, Maia RDCC, Giampaoli V, Teixeira EH, Arruda FVS, et al. Antifungal activity of lectins against yeast of vaginal secretion. Braz J Microbiol. 2012;43(2): 770-8.

45 Regente M, Taveira GB, Pinedo M, Elizalde MM, Ticchi AJ, Diz MS, et al. A sunflower lectin with antifungal properties and putative medical mycology applications. Curr Microbiol. 2014;69(1):88-95.

46 Sulzenbacher G, Roig-Zamboni V, Peumans WJ, Henrissat B, van Damme EJ, Bourne Y. Structural basis for carbohydrate binding properties of a plant chitinase-like agglutinin with conserved catalytic machinery. J Struct Biol. 2015;190(2):115-21.

47 Ziatabar S, Zepf J, Rich S, Danielson BT, Bollyky PI, Stern R. Chitin, chitinases, and chitin lectins: Emerging roles in human pathophysiology. Pathophysiology. 2018;25(4):253-62.

48 Bah CSF, Fang EF, Ng TB. Medicinal Applications of Plant Lectins. In Fang EF, NG TB, editors. Antitumor Potential and other Emerging Medicinal Properties of Natural Compounds. Dordrecht: Springer; 2013. 
49 Lusvarghi S, Bewley CA. Griffithsin: an Antiviral Lectin with Outstanding Therapeutic Potential. Viruses. 2013;8(10):1-18.

50 Uematsu J, Koyama A, Takano S, Ura Y, Tanemura M, Kihira S, et al. Legume Lectins Inhibit Human Parainfluenza Virus Type 2 Infection by Interfering with the Entry. Viruses. 2012;4(7):1104-15.

51 Maginnis MS. Virus-Receptor Interactions: The Key to Cellular Invasion. J Mol Bio. 2018;430(17):2590-2611.

52 Hopper JT, Ambrose S, Grant OC, Krumm SA, Allison TM, Degiacomi MT. The tetrameric plant lectin BanLec neutralizes HIV through bidentate binding to specific viral glycans. Structure. 2017;25(5): 773-82.

53 Coelho LCBB, Silva PMS, Oliveira WF, Moura MC, Pontual EV, Gomes FS et al, Lectins as antimicrobial agents. J Appl microbiol. 2018;125(5):1238-52.

$54 \mathrm{Ng} \mathrm{TB}$, Chan YS, Ng CCW, Wong JH. Purification and characterization of a lectin from green split peas (Pisum sativum). Appl Biochem. 2015;177(6):1374-85.

55 Fang EF, Lin P, Wong JH, Tsao SW, Ng TB. A lectin with Anti-HIV-1 Reverse Transcriptase, Antitumor, and Nitric Oxide Inducing Activities from Seeds of Phaseolus vulgaris cv. Extralong Autumn Purple Bean. J Agr Food Chem. 2010;58(4):2221-9.

56 Lam SK, Ng TB. Isolation and characterization of a French bean hemagglutinin with antitumor, antifungal, and antiHIV-1 reverse transcriptase activities and an exceptionally high yield. Phytomedicine. 2010;17(6):457-62.

57 Gondim AC, da Silva SR, Mathys L, Noppen S, Liekens S, Sampaio AH, et al. Potent antiviral activity of carbohydrate-specific algal and leguminosae lectins from the Brazilian biodiversity. MedChemComm. 2019;10(3):390-8.

58 Oliveira MD, Nogueira ML, Correia MT, Coelho LC, Andrade CA. Detection of dengue virus serotypes on the surface of gold electrode based on Cratylia mollis lectin affinity. Sensor Actuat B-Chem. 2011;155(2):789-95.

59 Pereira EM, Dario AF, França RF, Fonseca BA, Petri DF. Binding of dengue virus particles and dengue proteins onto solid surfaces. ACS Appl Mater Interfaces. 2010;2(9):2602-10.

60 Ko SM, Kwon J, Vaidya B, Choi JS, Lee HM, Oh MJ, et al. Development of lectin-linked immunomagnetic separation for the detection of hepatitis A virus. Viruses. 2014;6(3):1037-48

61 Andrade CA, Oliveira MD, De Melo CP, Coelho LC, Correia MT, Nogueira ML Diagnosis of dengue infection using a modified gold electrode with hybrid organic-inorganic nanocomposite and Bauhinia monandra lectin. J Colloid Interf Sci. 2011;362(2):517-23.

62 Mehrotra P. Biosensors and their applications-A review. JBCR. 2016;6(2):153-9.

63 Rahaie M, Kazemi SS. Lectin-based biosensors: as powerful tools in bioanalytical applications. Biotechnol. 2010;9(4):428-43.

64 Turner AP. Biosensors: sense and sensibility. Chem Soc Rev. 2013;42(8):3184-96.

65 Newsholme P, Cruzat VF, Keane KN, Carlessi R, de Bittencourt Jr, PIH. Molecular mechanisms of ROS production and oxidative stress in diabetes. Biochem J. 2018;473(24):4527-50.

66 Demidchik V. Mechanisms of oxidative stress in plants: from classical chemistry to cell biology. EEB. 2015;109:21228.

67 Pisoschi AM; Pop A. The role of antioxidants in the chemistry of oxidative stress: A review. Eur J Med Chem. 2015;97:55-74.

68 Poljsak B, Šuput D, Milisav, I. Achieving the balance between ROS and antioxidants: when to use the synthetic antioxidants. Oxi. 2013;2013:1-11.

69 Lacerda E, do Nascimento ES, de Lacerda JTJG, da Silva Pinto L, Rizzi C, Bezerra MM et al. Lectin from seeds of a Brazilian lima bean variety (Phaseolus lunatus L. var. cascavel) presents antioxidant, antitumour and gastroprotective activities. Int J Biol Macromol. 2015;95:1072-81.

70 Saha RK, Tuhin SHM, Jahan N, Roy A, Roy P. Antibacterial and Antioxidant Activities of a Food Lectin Isolated from the Seeds of Lablab purpureous. AJEthno. 2014;1(1):8-17.

71 Schaich KM, Tian X, Xie J. Reprint of "Hurdles and pitfalls in measuring antioxidant efficacy: A critical evaluation of ABTS, DPPH, and ORAC assays". J Funct Foods. 2015;18:782-96.

72 Pinto IR, Chaves HV, Vasconcelos AS, de Sousa FCF, Santi-Gadelha T, de Lacerda JTJ. Antiulcer and Antioxidant Activity of a Lectin from Mucuna pruriens Seeds on Ethanol-induced Gastropathy: Involvement of Alpha-2 Adrenoceptors and Prostaglandins. Curr Pharm des. 2019;25(12):1430-9.

73 Cheng DL, Zhu N, Li CL, Lv WF, Fang WW, Liu Y, et al. Significance of malondialdehyde, superoxide dismutase and endotoxin levels in Budd-Chiari syndrome in patients and a rat model. Exp The Med. 2018;16(6):5227-5235.

74 Gaucher C, Boudier, A, Bonetti J, Clarot I, Leroy P, Parent M. Glutathione: Antioxidant Properties Dedicated to Nanotechnologies. Antioxidants. 2018;7(62):1-21.

75 Younus, H. Therapeutic potentials of superoxide dismutase. Int. J. Health Sci. 2018;12(3):88-93. 
76 Freitas FP, Porto ML, Tranhago CP, Piontkowski R, Miguel EC, Miguel TB, et al. Dioclea violacea lectin ameliorates oxidative stress and renal dysfunction in an experimental model of acute kidney injury. Am J Transl Res. 2015;7(12):2573-88.

77 Sureshbabu A, Ryter SW, Choi ME. Oxidative stress and autophagy: crucial modulators of kidney injury. Redox Biol. 2015;4(2015):208-14.

78 Odekanyin OO, Kayode AS, Adewuyi JO. Purification, Characterization and Antioxidant Potential of a Novel Lectin from Pterocarpus soyauxii Taub Seeds. Not Sci Biol. 2019;11(1):112-21.

79 Odekanyin OO, Akande OO. In-vitro Antioxidant and Antibacterial Potential of Mannose/Glucose-binding Pterocarpus osun Craib. Seeds Lectin. J Appl. 2019;1-14.

80 Cherrak SA, Mokhtari-Soulimane N, Berroukeche F, Bensenane B, Cherbonnel A, Merzouk H. In Vitro Antioxidant versus Metal Ion Chelating Properties of Flavonoids: A Structure-Activity Investigation. PloS One. 2016;11(10).

81 Gaschler MM, Stockwell BR. Lipid peroxidation in cell death. Biochem Biophys Res Commun. 2017;482(3):41925.

82 Rathore R, McCallum JE, Varghese E, Florea AM, Büsselberg D. Overcoming chemotherapy drug resistance by targeting inhibitors of apoptosis proteins (IAPs). Apoptosis. 2017;22(7):898-919.

83 Gondim AC, Romero-Canelón I, Sousa EH, Blindauer CA, Butler JS, Romero MJ, et al. The potent anti-cancer activity of Dioclea lasiocarpa lectin. J Inorg Biochem. 2017;175:179-89.

84 Hamid R, Masood A, Wani IH, Rafiq S. Lectins: Proteins with Diverse Applications. J Appl Pharm Sci. 2013;3(4):93103.

85 He S, Simpson BK, Sun H, Ngadi MO, Ma Y, Huang T. Phaseolus vulgaris Lectins: A Systematic Review of Characteristics and Health Implications. Crit Rev Food Sci. 2018;58(1):70-83.

86 Cagliari R, Kremer FS, da Silva Pinto L. Bauhinia lectins: Biochemical properties and biotechnological applications. Int. J. Biol. Macromol. 2018;119:811-20.

87 Zhang, S, Tian M, Zhang SY, Xie T, Chen DY, et al. Plant lectins, from ancient sugar-binding proteins to emerging anti-cancer drugs in apoptosis and autophagy. Cell Prolif. 2015;48(1):17-28.

88 Yau T, Dan X, Ng CCW, Ng TB. Lectins with potential for anti-cancer therapy. Molecules. 2015;20(3):3791-810.

89 Silva MC. Bauhinia forficata lectin (BfL) induces cell death and inhibits integrin-mediated adhesion on MCF7 human breast cancer cells. Biochim Biophys Acta. 2014;1840(7):2262-71.

90 Gondim AC, Romero-Canelón I, Sousa EH, Blindauer CA, Butler JS, Romero MJ. et al. The potent anti-cancer activity of Dioclea lasiocarpa lectin. J Inorg Biochem. 2017;175:179-89.

91 Lam SK, $\mathrm{Ng}$ TB. Isolation and characterization of a French bean hemagglutinin with antitumor, antifungal, and antiHIV-1 reverse transcriptase activities and an exceptionally high yield. Phytomedicine. 2010;17(6):457-62.

92 Fang EF, Pan WL, Wong JH, Chan YS, Ye XJ, Ng TB. A new Phaseolus vulgaris lectin induces selective toxicity on human liver carcinoma Hep G2 cells. Arch Toxicol. 2011;85(12):1551-63.

93 Chan YS, Xia L, Ng TB. A glucosamine-specific lectin from green dragon no. 8 beans (Phaseolus vulgaris) induced apoptosis on nasopharyngeal carcinoma cells. Evid Based Complement Alternat Med. 2015;2015:1-8.

94 Rafiq S, Majeed R, Qazi AK, Ganai BA, Wani I, Rakhshanda S, et al. Isolation and antiproliferative activity of Lotus corniculatus lectin towards human tumour cell lines. Phytomedicine. 2013;21(1): 30-8.

95 Faheina-Martins GV, da Silveira AL, Cavalcanti BC, Ramos MV, Moraes MO, Pessoa C, et al. Antiproliferative effects of lectins from Canavalia ensiformis and Canavalia brasiliensis in human leukemia cell lines. Toxicol In Vitro. 2012;26(7):1161-9.

96 Yassin AM, El-Deeb NM, Elsaid FG, Shati AA, Cioca G, Tit DM, et al. Lectin from Pisum fulvum Seeds as in vitro Anticancer and Apoptotic Gene Regulator. Rev Chim-Bucharest. 2019;70(4):1490-5.

97 Koiri RK, Mehrotra A, Trigun SK. Dalton's Lymphoma as a Murine Model for Understanding the Progression and Development of T-Cell Lymphoma and its Role in Drug Discovery. Int J Immunother Cancer Res. 2017;3(1):1-6.

98 De Oliveira Silva F, das Neves Santos P, de Oliveira Figueirôa E, de Melo CML, Neves JKDAL, Arruda FVS, et al. Antiproliferative effect of Canavalia brasiliensis lectin on B16F10 cells. Res Vet Sci. 2014;96(2):276-82.

99 Kuzu OF, Nguyen FD, Noory MA, Sharma A. Current State of Animal (Mouse) Modeling in Melanoma Research. Cancer Growth Metastasis. 2015;8(S1):81-94.

100 Osterne VJS, Silva-Filho JC, Santiago MQ, Pinto-Junior VR, Almeida AC, Barreto AAGC, et al. Structural characterization of a lectin from Canavalia virosa seeds with inflammatory and cytotoxic activities. Int $\mathrm{J}$ Bio Macromol. 2017;94:271-82.

101 Leal RB, Pinto-Junior VR, Osterne VJS, Wolin IAV, Nascimento APM, Neco AHB, et al. Crystal structure of DlyL, a mannose-specific lectin from Dioclea lasiophylla Mart. Ex Benth seeds that display cytotoxic effects against C6 glioma cells. Int J Bio Macromol. 2018;114:64-76. 
102 Nascimento APM, Knaut JL, Rieger DK, Wolin IA, Heinrich IA, Mann J, et al. (2018). Anti-glioma properties of DVL, a lectin purified from Dioclea violacea. Int J Bio Macromol. 2018;120:566-77.

103 Giakoumettis D, Kritis A, Foroglou N. C6 cell line: the gold standard in glioma research. Hippokratia. 2018;22(3):105-12.

104 Chen J, Liu T, Gao J, Gao L, Zhou L, Cai M, et al. Variation in Carbohydrates between Cancer and Normal Cell Membranes Revealed by Super-resolution Fluorescence Imaging. Adv. 2016;3(12):1-9.

105 Sprawka I, Goławska S, Parzych T, Goławski A, Czerniewicz P, Sytykiewicz H. Induction of apoptosis in the grain aphid Sitobion avenae (Hemiptera: Aphididae) under the influence of phytohaemagglutinin PHA. Appl Entomol Zool. 2013;48(4):525-32.

106 Hassan M, Watari H, AbuAlmaaty A, Ohba Y, Sakuragi N. Apoptosis and Molecular Targeting Therapy in Cancer. Biomed Res Int. 2014;2014:1-20.

(c) 2021 by the authors. Submitted for possible open access publication under the terms and conditions of the Creative Commons Attribution (CC BY NC) license (https://creativecommons.org/licenses/by-nc/4.0/). 